\title{
Cooperative Principle in Oral English Teaching
}

\author{
Mai Zhou \\ School of Foreign Languages, Zhejiang Gongshang University \\ 18 Xue Zheng Street, Hangzhou 310018, China \\ E-mail: zhoumai6993@sohu.com
}

\begin{abstract}
The Cooperative Principle by American linguist Grice is one of the major principles guiding people's communication. Observing the Cooperative Principle will be helpful for people to improve the flexibility and accuracy of language communication. The ultimate aim of spoken English teaching is to develop students' communicative competence. Therefore, it is significant to apply the Cooperative Principle to oral English teaching. This paper tries to prove the applicability of Cooperative Principle in spoken English teaching.
\end{abstract}

Keywords: Cooperative Principle, Oral English teaching, Communicative competence, Pragmatics

\section{Introduction}

Grice's concept of the Cooperative Principle and its four associated maxims are considered a major contribution to the area of pragmatics, which not only plays an indispensable role in the generation of conversational implications, but also is a successful example showing how human communication is governed by the principle.

In foreign language teaching, the four basic skills have been greatly improved for Chinese college students in the past decades. However, these skills have not been developed at the same pace, especially the ability in speaking. Some college students can understand what others say in English but cannot express themselves effectively in English, and some even cannot catch others' meaning conveyed by spoken English. Speaking still remains the most difficult skill for the majority of college students, who remain poor in oral communication in English after years of study in universities. This phenomenon has a close relation with the pedagogy of spoken English. My paper is devoted to setting out the theory of Cooperative Principle and its application to spoken English teaching.

\section{A Brief Account of the Cooperative Principle}

\subsection{The Concept of Cooperative Principle and Its Maxims}

In the book entitled Logic and Conversation, Grice provides us with the definition of Cooperative Principle, i.e. make your contribution such as is required, at the stage at which it occurs, by the accepted purpose of the talk exchange in which you are engaged (1975, p.45). During the selection of the categories, the connection with human rationality is highlighted. Under the principle, there're four maxims (1975, pp.45-46):

I. The maxim of Quantity (concerning the amount of information to be conveyed):

(1) Make your contribution as informative as is required (for the current purposes of exchange).

(2) Do not make your contribution more informative than is required.

II. The maxim of Quality (try to make your contribution one that is true, specifically):

(1) Do not say what you believe to be false.

(2) Do not say that for which you lack adequate evidence.

III. The maxim of Relation (make your contributions relevant).

IV. The maxim of Manner (concerning not so much what is said as how it is said, be perspicuous):

(1) Avoid ambiguity.

(2) Avoid obscurity of expression.

(3) Be brief (avoid unnecessary prolixity).

(4) Be orderly.

It is said that the conversation would be most successful if the principle and these maxims would be complied with. But people always violate this principle or these maxims, which make the conversation partially successful or simply a failure, or generate conversational implication.

\subsection{The Function of Cooperative Principle}

In reality, people who go into conversation with each other follow the maxims of Cooperative Principle, that is, both the 
speaker and listener are assumed to want the conversation to work. Its maxims specify what participants have to do in order to talk in a rational, efficient, and cooperative way and that they should speak sincerely, relevantly and clearly while providing sufficient information (Levinson,1987, p72).Cooperative Principle is a guarantee for successful communication and a premise for the generation of any conversational implication. Moreover, the Cooperative Principle is a successful example showing how human communication is governed by general principles.

\subsection{The Application of Cooperative Principle}

As the cornerstone theory of pragmatics, the Cooperative Principle is one of the major principles guiding people's communication. The Principle and its maxims can clearly expound the literary meaning and its implication of communication. Therefore, the principle can be applied to various areas. The following conversation is between Premier Enlai Zhou and an American journalist (A: Premier Zhou Enlai; B: American journalist):

B: Mr. Premier, could you please tell me, why you Chinese having high aspiration and boldness of vision still use the pen made in U. S.A.?

A: Talking about this pen, there's a long story. This is not an ordinary pen. It's war booty, in fighting against the U. S. troops, sent by a Korea friend of mine, as a souvenir. I thought it significant, and accept this pen, which is manufactured in your country.

This is a typical example which violates the maxim of relation and the maxim of quantity. The American journalist intends to laugh at China, the country he considers to be lagging behind the U.S.A. However, Premier Zhou Enlai does not answer the question directly, but chooses to violate the conversational principle. It is a common pen but with great meaning. He calls the pen a souvenir from a Korea friend, which stands for the failure of American troops in the War to Resist U.S Aggression and Aid Korea. Premier Zhou's answer shows his outstanding diplomatic competence.

Cooperative Principle and conversational implication by H. P. Grice, as a branch of pragmatics, has played an important part in the practice of translation. Translation is a dynamic communicative activity going between two languages, and changes with the communicative context, the mental, cognitive, cultural, social and linguistic factors related to both participants. Translation process can be analyzed from the perspective of Cooperative Principle.

"mian hua wo liu"is a euphemistic idiom in Chinese culture, which means having sexual relation with prostitutes. However, we can break the maxim of Quality of Cooperative Principle, and literarily translates it into "frequented the budding groves". It is rather difficult for readers to understand the implication of the phrase. As a result pragmatics must be introduced and employed into the translation,.

What's more, it is feasible to apply the Cooperative Principle to listening class. Listening class is part and parcel in English language teaching. Focusing on Cooperative Principle in inferring the conversational implication, we find that the principle can improve students' competence in listening comprehension.

The following example is from CET-6: (W: woman, M: man)

Example: W: Be careful, John. That car is speeding.

M: You have to keep an eye out for motorcycles, too.

Q: What does the man mean?

A) He sees a nice motorcycle.

B) Motorcycles look nicer than cars.

C) Motorcycles can be dangerous, too.

D) Motorcycles are as fast as cars.

In the above conversation, the man violates the maxim of Relation. We realize that his answers seem irrelevant to the woman's questions. In the conversation, the woman reminds the man that a car near theirs is speeding, but the man replies that she should pay attention to the motorcycles. We can infer that his implication should be car speeding and motorcycle speeding are both dangerous. Therefore, the correct answer should be $\mathrm{C}$.

\section{Spoken English Teaching}

\subsection{The Current Situation of Spoken English Teaching}

With the development of economy in China, Chinese students' enthusiasm for English learning has reached its climax. Spoken English, as a major part of communication, is gaining unprecedented momentum. Accordingly, the teaching of spoken English is put on agenda. We note that the College English Syllabus has following stipulations:

Language is a tool for communication; the ultimate aim of language teaching is to foster students' the ability of communication both orally and through written channel. Language teaching should not only aim at the development of the students' linguistic competence but also at the development of their communicative competence. 
In traditional teaching of spoken English, teachers focus on grammar, discourse analysis, dull repetition and water-down form of language teaching. They always neglect an important thing, i.e. the application of language. As a result, those approaches of teaching lead to students' poverty in skills to apply what they have learned from books to communication, though they are very capable of dealing with linguistic problems. Especially in intercultural communication, misunderstandings often come into being due to inappropriate selection of words and sentences.

Therefore, spoken English competence of students in China is by no means satisfactory.

\subsection{The Reasons for Poor Spoken English of Students}

\subsubsection{The Poverty of Practice for Students}

Because college enrollment enlarges steadily, there are more than 40 or 50 students or even 80 or 90 students in each spoken English class in many universities and colleges. Therefore, it is hard for the teachers to offer a practice opportunity to every student in class. Besides, after class, there is a short of English practice and English atmosphere for many students.

\subsubsection{Less Attention being Paid to the Teaching of Pragmatics}

As we all know, traditional teaching of spoken English often neglects the introduction of the knowledge of pragmatics. Like Cooperative Principle, Politeness Principle, Speech Acts are several basic principles of pragmatics which guide people's communication. However, in today's spoken English teaching, we seldom acquire to knowledge. Lacking pragmatic knowledge makes us result in achieving a successful communication in intercultural communication.

\subsubsection{Lack of Interactions}

Judging from the current situation of spoken English teaching in China, we can easily find that teachers play the dominant role in classroom teaching, and the students are mainly passive listeners. Open questions or the topics which the students have passion for are not sufficiently dealt with. Last but not the least, some learners who lack confidence in their ability to participate successfully in oral interaction often keep silent while others speak enthusiastically. All in all, we realize that there are limited interactions between the teachers and their students and among the students.

\section{How Cooperative Principle Guides Spoken English Teaching}

\subsection{The Principle of Spoken English Teaching}

The traditional principle of spoken English teaching is based on 'Three Ps' Methodology: Presentation-Practice-Production. However, how does one 'practice' narrative evaluation? How does one 'produce' discourse markers naturally? How does one 'present' transaction boundaries? (Michael McCarthy, 2006, p67). By asking those questions, we note that the 'Three Ps' teaching method seems not so effective in spoken English teaching. Hence, Michael McCarthy in his book proposes an alternative methodology to supplement the 'Three Ps' named 'Three Is', which is as follows:

Illustration-Interaction-Induction. Illustration means looking at real data where possible. Interaction means talk among learners and teachers about language, sharing and forming views, breaking down cultural barriers and stereotypes. Induction means drawing conclusions. (2006, p67).

\subsection{The Aims of Spoken English Teaching}

The main purpose of English language teaching is to improve learners' communicative competence, namely, the ability of oral English communication. Teaching is the communication between teachers and students, and the result of interactions. Since the ultimate aim of spoken English teaching is communication, we should enhance students' oral abilities.

\subsection{The Application of Cooperative Principle in Spoken English Teaching}

\subsubsection{The Relation between Cooperative Principle and Spoken English Teaching}

The notion of Cooperative Principle is relevant to the spoken English teaching in many ways. First, the Cooperative Principle is one of major principles which guide people's communication, and the ultimate aim of spoken English teaching is communication. Second, the aim of spoken English teaching is to improve students' communicative competence, and Cooperative Principle can have positive effect on spoken English teaching. Third, in order to work out the conversational implication (which I will talk about in following part) in spoken English teaching, it is necessary for the students to master the basic knowledge of Cooperative Principle. As a result, the Cooperative Principle can be applied to the teaching of spoken English.

\subsubsection{The Violation of Cooperative Principle and Conversational Implication}

The four maxims can be violated for various reasons, but only when they are "flouted", or violated blatantly, i.e. both the speaker and the hearer are aware of the violation, does conversational implication occur. 


\subsubsection{Violating the Quantity Maxim}

The maxim of quantity makes us make our contribution as informative as is required for the current purpose of the exchange and do not make our contribution more informative than is required. However, a speaker violates the Quantity maxim and invites the hearer to consider the conversational implication by saying more (that is, providing more information) or less (providing less information) than is required. Let's see how the maxim of quantity is flouted in the following examples:

Example:

A: Are you able to find the type of ink cartridge I need for my printer?

B: Well, yes I do, you should visit that new office building because they have hundreds of printer cartridges, all you'd ever want to see or buy, and my son works there, you know, he is a very intelligent man.

\section{A: Boss B: Secretary}

The conversation is between a manager and his secretary in their office. Instead of just saying "Yes", we can easily find that the secretary violates the maxim of Quantity, because she provides much more information than the manager actually needs. The implication of her utterances is that she would like to introduce her son to the manager.

\subsubsection{Violating the Quality Maxim}

The maxim of quality requires us not to say what we believe to be false and what we lack adequate evidence. The violation of the Quality maxim is realized by saying things that are not true.

The following example is the analysis of conversational implications generated by flouting the Quality Maxim of the Cooperative Principle. People often use polite and indirect strategies to express their real meanings.

Example:

A: What do you think of Jason?

B: He is a good friend. He always keeps eye on my pocket.

This example shows us that how the maxim of Quality is breached. When A asks B the question, he may have already thought that Jason is not a good friend, and he wants to ensure that B has the same opinion with him. But B deliberately says that Jason is a good friend, which himself considers to be incorrect. Then B adds that Jason always asks him for money. The reason why B says so indirectly is that he wants to save Jason's face.

\subsubsection{Violating the Relation Maxim}

The violation of the Relation Maxim means that the utterance of the speaker is irrelevant to the context for some reasons. Some conversational implications are produced by violation of the relation maxim. The speaker may not say anything explicitly related to the topic of the conversation but invite the hearer to seek for an interpretation of possible relevance. The following example can be used to analyze conversational implications produced by the violation of Relation Maxim.

Example:

Tom: Tom is such a noisy man, isn't he?

Dick: I saw a fantastic movie yesterday. (TEM8)

This is a dialogue between two roomates; Dick's answer flouts the maxim of relation. What can we know from Dick's answer? He did not want to talk more about Tom's topic.

\subsubsection{Violating the Manner Maxim}

The violation of the manner maxim means giving obscure and ambiguous information.

Below we analyze how the following example violates the Manner Maxim that gives rise to conversational implications.

Example:

Teacher A: Shall we get something for the kids?

Teacher B: Yes. But I veto C-A-N-D-Y. (TEM8)

Here Teacher B intentionally breaks the maxim of Manner by spelling out the word "candy", and thereby conveys that Teacher B would rather not have candy mentioned directly in the presence of the children, in case they are prompted to demand some.

\section{The Enlightenment to Spoken English Teaching}

\subsection{Lay a Solid Foundation of Spoken English for Students}

In order to make students observe the Cooperative Principle, spoken English teaching can not be limited to conversation 
practice, listening and reading practice are significant as well, for they can be helpful to lay a solid foundation of speaking for students. Teachers should make students have a clear understanding that oral ability is based on listening comprehension, and listening comprehension is based on the reading comprehension.

\subsection{Innovating the Methods of Spoken English Teaching}

Based on Grice's Cooperative Principle, teachers should be conscious of cultivating students' sense of cooperation. Creating free, active classroom atmosphere will be helpful for teachers to develop students' potential of English language learning and strengthen the friendly cooperation and communication between the teacher and students and among the students. English learning should be a social activity. When considering about the teaching aims and teaching requirements, teachers should take students' abilities, interests and hobbies into account at the same time. Innovating the methods of oral English teaching and using some free and cooperative teaching methods, such as role-play, impromptu speech, and topic discussion, group debate and so on can make classroom teaching interesting and lively.

\subsection{Compiling Suitable Textbooks}

The goal of spoken English teaching is to develop students' communicative competence. It is properly implied that pragmatic competence is a part of communicative competence. Because of that, the textbooks of oral English teaching should cover some rudimentary knowledge of pragmatics and give students a fundamental understanding of pragmatics. What's more, the selection of oral materials should also be stressed in textbooks compiling. Materials from literature conversation, classic film dialogues in films, and daily conversation and so on are best choice for those textbooks, whatever materials we select should be from real oral functions bank.

\subsection{Activating the Students in Spoken English Teaching}

Spoken English teaching is a bilateral activity between teachers and students. Successful teaching and learning require active cooperation between teacher and students. During the teacher and student oral interaction, raising questions is a significant way. For questioning interaction between teachers and students is a way of feedback for teachers to check the effect of teaching and learning. Students develop their creativity and improvisational ability in the process of preparing and answering the referential questions. The interaction among the students are vital in oral activities, such as situation dialogue,role play, conversation,information-gap, survival games, debate on current issues and so on. According to Johnson (2000, pp13-14), student to student interaction can enhance students' abilities to work collaboratively and foster positive attitudes toward English learning, student to student interaction cannot become an ignorable dimension of classroom communication.

\section{Conclusion}

Oral English teaching has always been a drawback in College English teaching though both teachers and students consider it necessary to reinforce the oral English training so as to improve students' oral English competence. Practical oral English teaching is confronted with many difficulties. As a cornerstone theory of pragmatics, the Cooperative Principle is one of the major principles guiding people's communication. The principle and its maxims can neatly expound what is literary meaning and its implication in communication. Applying the Cooperative Principle in spoken English teaching can be conducive to developing students' communicative competence, which is viewed as the ultimate aim of oral English teaching.

Unavoidably, limitations are guaranteed to exist in my study. Hence I hope this will be overcome or supplemented through others' deeper research and exploration on the topic.

\section{References}

George Yule. (2001). Pragmatics. Shanghai: Shanghai Foreign Language Education Press, pp. 151-154.

Green, Georgia M. (1989). Pragmatics and Natural Language Understanding. Hillsdale, N.J.: Erlaum., pp.21-30.

Grice, H. P. (1957). Meaning. Philosophical Review. In P. Strawson(1967), Philosophical Logic. Oxford: Oxford University Press. pp. 281-304

Grice, H. P. (1975). Logic and Conversation. Cambridge: Cambridge University Press. pp.45-46.

Johnson, Karen E. (2000). Understanding Communication in Second Language Classrooms. Beijing: People's Education Press. pp13-14.

Leech, G.N. (1983). Principles of Pragmatics. London: Longman. pp. 81-84.

Levinson, C. S. (1987). Pragmatics. Cambridge: Cambridge University Press, p72.

Levinson, C. S. (2001). Pragmatics. Beijing: Foreign Language Teaching and Research Press\&Cambridge: Cambridge University Press. p40.

Michael McCarthy. (2006). Spoken Language \& Applied Linguistics. Shanghai: Shanghai Foreign Language Education Press. p67. 